\title{
Food Safety as a Key Factor in the Supply Chain
}

\author{
Andrzej Szymonik \\ ORCID ID: 0000-0002-7846-3859 \\ Lodz University of Technology, Poland \\ Daniel Chudzik \\ ORCID ID: 0000-0001-6578-5193 \\ Kilargo Sp. z o.o., Poland
}

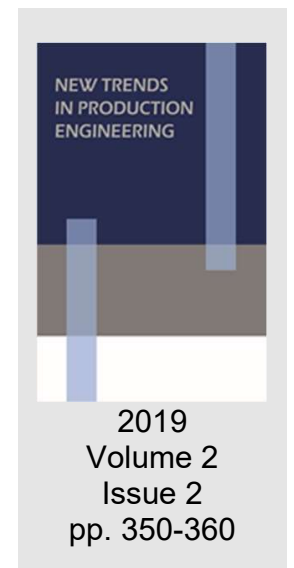

Date of submission to the Editor: 09/2019

Date of acceptance by the Editor: 11/2019

\section{INTRODUCTION}

Food safety in the supply chain is one of the key factors that in the near future, are going to be carefully examined and controlled. More and more often, there are reports of acts of terrorism that are beginning to have their source in food production.

Annually, in the United States, 5 thousand people die of foodborne diseases. In Poland, 80 thousand cases of foodborne illnesses are reported. In fact, there are many more. Food manufacturers should be developing standards for safe food production, and in doing so, they should be able to get the support of public administration. Unless food industry organizations cooperate for the safety of food, consumers will be the victims of potential foodborne illnesses. Rather than plague companies with inspections (checks), the established supervisory authorities should work on what could be done to make production at specific food processing plants safer taking into account organizational, technical, and regulatory solutions (www.portalspozywczy.pl, 2018).

\section{FOOD IN REAL-LIFE CONDITIONS}

Food and its packaging, as any other product, should satisfy the needs of manufacturers, logisticians, and consumers by meeting certain specifications: physical (e.g. dimensions and weight that facilitate transport and warehousing), chemical (e.g. composition of raw materials and their effect on the body, packaging, and environment), technological (e.g. ease of processing, storage), organoleptic (e.g. pleasant sensory feelings - tactile, gustatory, olfactory), functional (e.g. ease of opening, preparation, utilization, traceability), economic (price, cost of preparation, utilization, transport), aesthetic (e.g. colour, shape), safety (e.g. harmfulness, healthfulness, facility of monitoring the quality of a product, anti-theft or damage protection).

All of the presented requirements are important, however, those that have an effect on human health, life, and the natural environment are particularly 
consequential. As evidenced in real life, products that should never be marketed unfortunately, sometimes are. Below follow a few examples:

The first. In 2012, in the Czech Republic, tainted alcohol was made and marketed by its distributors in their national market as well as in Slovakia and in Poland, as a result of which 38 people died and many more suffered from methanol poisoning (Szymonik, 2016).

The second. In the vicinity of Kalisz, two companies manufacturing powdered egg, had been committing acts of negligence and violations. For many years, the quality and purity of the powdered egg manufactured there had been questionable. The product contained heavy metals and bacteria from the E. coli group. They had been manufacturing the powdered egg since 2008 , yet it was only in 2012 that the infringements were discovered. Impounded were almost 26 tonnes of the powdered egg that would have otherwise been sold to over 100 Polish manufacturers of pâté, confectionery, and pasta. There were also international leads in the inquiry into the very same powdered egg pointing to the Czech Republic and the Netherlands. It turned out that one of the suspects in the case purchased the product from a supplier residing in the lódzkie voivodeship who, in turn, imported powdered egg mix from abroad (Szymonik, 2016).

The third. In 2012, in Poland, fraudulent distribution of salt was uncovered. Industrial salt, which looks similar to food grade salt, was substituted for it. The salt had been used in 646 cake shops, restaurants, bakeries, including Tesco and Auchan bakeries. The chemical composition of industrial salt poses a significant health risk because it contains potassium or potassium nitrate that may affect cardiac action or even lead to heart failure. Industrial salt is considered a technological waste product: it is produced by precipitation during the manufacturing of calcium chloride. It can be used for road maintenance (Szymonik, 2016).

The fourth. In 2017, in Germany, insecticide contamination of eggs was discovered. From the Netherlands and Belgium to Germany, more than 10 million contaminated eggs were imported altogether. Higher doses of an insecticide known as fipronil may lead to liver, pancreas, and kidney failure. The contaminated eggs were withdrawn from the German market and destroyed. The World Health Organization (WHO) classifies the compound as 'moderately toxic'. In the European Union, fipronil is forbidden from use in animals that are intended for human consumption (www.portalspozywczy.pl, 2018).

The fifth. In 2016, in Sweden, 19 tonnes of Polish apples were withdrawn from the market. The reason - the level of residue chemicals used for spraying apple trees was found to exceed the maximum permissible level eight-times in the apples. The Swedish National Food Agency reported the situation to the European Commission. Allowedly, having supported the Western World in imposing sanctions against Russia, Poland has lost a large and promising Russian market for its agricultural products including apples. And even though the Polish government is satisfied with the rate at which the loss is being made up for - from Africa to Asia, producers and vendors know all too well that finding 
new markets and building a reputation of a reliable supplier are no mean feat and require time (www.wolnemedia.net, 2017).

Based on the presented examples, it may be concluded that if we know precisely where raw materials come from, who ships and stores them, where they are used in production, and who the distributor is, we are able to reduce the number of counterfeit, unsafe products reaching the customer with the caveat that an adequate and safe system be built throughout all stages of production, processing, and distribution to enable quick identification of suppliers and direct customers. Helpful in this regard is a system known as traceability.

However, as evidenced in day to day life, no system is perfect enough to safeguard food against wilful attempts of contamination committed by lunatics, terrorists. One example is a situation in Germany where an unknown extortionist demanded 10 million euro from retail networks lest s/he should plant contaminated food products in supermarkets across Germany and other countries. The offender or offenders warned in an email sent to the police, retail companies, and consumer organizations that starting from September $16^{\text {th }}$, 201720 poisoned food products would be placed in stores, unless they were paid several million euro. The extortionist did not specify what products would be placed in what regions or stores. S/he proclaimed that $s /$ he intended to strike German food companies across the country. To prove his/her determination, shortly before closing on Saturday, September $16^{\text {th }}$, the offender placed 5 poisoned food products in a store in Friedrichshafen in Baden-Württemberg. The extortionist informed the police, which allowed them to remove the products promptly. The poison used by the extortionist belonged to the class of glycols. No further details were provided for the sake of the investigation. In all likelihood everything ended well, which is good. Should things have gone a different way, the consequences could have been catastrophic (http://wiadomosci.onet.pl, 2017).

Dependability of logistic processes, both upstream and downstream, is not only an area of interest for its participants; it is also a matter of particular concern as regards the efficiency and effectiveness of its management. Supply chain safety, along with food supply, includes 'end-to-end' safety which involves, among others (European Commission, 2011):

- improvement of the level of safety of the supply chain (focusing on creating conditions that ensure unimpeded flow of goods, including food products);

- implementing safety certificates taking existing systems into account;

- common safety assessment suitable for all modes of transport in an effort for international cooperation in the fight against terrorism and other criminal activities such as piracy.

It must be allowed that a modern, innovative approach to management in the context of relationships that derive from the safety of the supply chain, including food supply, makes it possible to create a synergy effect.

Food and its packaging, as any product, should satisfy the needs of manufacturers, logisticians, and consumers by meeting certain specifications: 
physical (e.g. dimensions, weight that facilitate transport and warehousing), chemical (e.g. composition of raw materials and their effect on the body, packaging, and environment), technological (e.g. ease of processing, storage), organoleptic (e.g. pleasant sensory feelings - tactile, gustatory, olfactory), functional (e.g. ease of opening, preparation, utilization, traceability), economic (price, cost of preparation, utilization, transport), aesthetic (e.g. colour, shape), safety (e.g. harmfulness, healthfulness, facility of monitoring the quality of a product, anti-theft or damage protection).

Traceability, otherwise called the TTC (Track, Trace and Control), enables: tracking the path of the product from the moment of its manufacture from raw materials until it reaches the end customer in the supply chain; recording parameters identifying the goods and mapping their flow.

Traceability enables precise identification of processes in the physical flow in the supply chain provided that all its participants follow the same rules and norms, e.g. GS1 standards, and EU regulations.

Principal GS1 standards include: identification of trade items (goods) - GTIN (GTIN-8, GTIN-12, GTIN-13, GTIN-14); identification of logistic units - SSCC; physical location identification - GLN; description of standards, bar codes, EPC, eCom electronic communication, and others.

The standards listed above define and ensure that all traced goods or cargo are identifiable thanks to the use of standardized identifiers; an identification stays on the goods/cargo until tracking is complete; all locations are identified with a unique GLN number in the entire supply chain; data on products and their physical flow are collected and shared as agreed on by trade partners (e.g. GDSN, EDI, online EPCIS solutions) (Hałas, 2012).

Mention should be made of other very spectacular world cases that were directly related to the interference with food. In 2008 and 2009, the United States and Canada found evidence that peanut butter paste was contaminated with salmonella, causing 9 deaths and affecting another 637 people, (Layton \& Miroff, 2009). In 2008, pork goods produced in Ireland were contaminated by dioxin and affected international suppliers in several countries (EFSA, 2008). In China, milk powder was adulterated with melamine and was associated with 6 deaths and 294,000 contaminated people (Spencer, 2009). In 2011, bean sprouts produced in Germany were contaminated by $\mathrm{E}$. coli, resulting in 37 deaths and another 3,000 people contaminated (Marucheck, 2011). These episodes and their consequences claim urgent and rigorous treatment, as they cause serious problems for public health and firms' value and profits (Resende Filho \& Hurley, 2012; Roth, 2008).

These contamination events are partially related to changes in modern supply chains, such as the globalization of food produce, consolidation of large companies, and commoditization of food products (Roth, 2008). These changes put pressure on producers to reduce cost (Tang \& Babich, 2014), which, in turn, respond by reducing the investment in safety actions. Also, in global supply chains, the distribution centres play another essential role in helping the prevention of safety hazards, because they store food products and can detect 
food contamination before such food reaches the consumers (CheboluSubramanian and Gaukler, 2015, Lao, 2012). The number of tiers in the chain, for example, also influences the risk of food contamination, because the existence of many interacting elements increases the likelihood of chemical and physical contamination (Reiner \& Trcka, 2004, Sloane \& O'Reilly, 2013, Van der Gaag, 2004).

\section{FOOD SAFETY IN SELECTED COMPANIES}

According to experts, even the best of practices and instructions, the latest techniques and technologies will be of no use, if people fail, which is especially true for the production of FCMG (fast-moving consumer goods) products because this is where, in case of contamination, food poisoning could affect an inordinate number of people threatening human life, human health, and the natural environment.

In Poland, in the recent years, the unemployment rate has been declining. In September of 2017 , it was below $7 \%(6.9 \%$ to be exact). One of the consequences of such a state of affairs is that there is a shortage of workers in the Polish job market, which usually negatively impacts on regular operation of enterprises, national economy.

For employers in sectors such as trade, sales, finance, industry, and construction, this typically means that they are under pressure to find skilled as well as unskilled workers. As evidenced in everyday business practice, one of the ways to alleviate the problem is to hire seasonal workers, migrants. Once they are hired, a number of questions arise:

- do seasonal workers guarantee food quality and food safety?

- how many seasonal workers are Polish and how many are foreign nationals (what is the proportion?)?

- do enterprises have in place technical systems that guarantee food safety taking into consideration this new situation?

- are there legal (organizational) procedures and documentation to minimize the risk of contamination (acts of terrorism)?

To fully answer these questions is no mean feat because it is rather challenging to collect reliable data due to a lack of respondents who either do not want to discuss this sensitive subject being afraid of retribution or resort to data protection regulations as an excuse not to speak.

Nevertheless, an attempt to study the problem was made with the participation of 15 companies in the group of middle-sized ( 7 - the lowest headcount of 90) and large enterprises ( 8 - the largest headcount of 3000 ). All the companies were food industry companies and dealt in the manufacture of ice-cream, frozen vegetables, frozen fish, frozen pizza, and frozen farinaceous products.

The developed survey questionnaire is a novelty because the study was concerned with food safety in food companies in the light of seasonal worker hire. The study focused on hiring procedures and organization of access of the hired workers to production lines. 
Responses to the question: Does the company employ Polish or foreign seasonal workers? showed that none of the responding companies employed exclusively Polish nationals, $20 \%$ of the respondents employed only foreign nationals, whereas $80 \%$ of the respondents hired both Polish as well as foreign seasonal workers (Fig. 1).

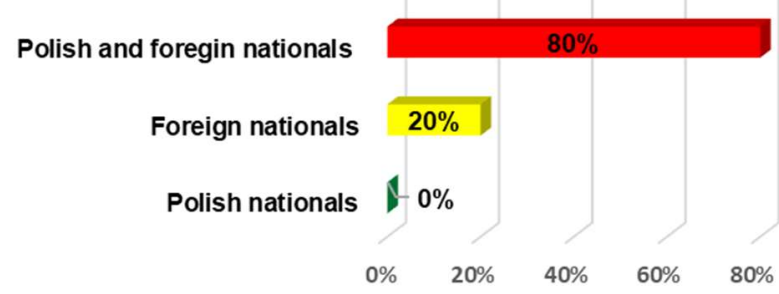

Fig. 1 Specifics of seasonal worker hire

An analysis of the results revealed that seasonal workers were hired by most companies without any background check $-87 \%$, whereas only $13 \%$ were hired on the basis a submitted CV or a motivational letter (Fig. 2).

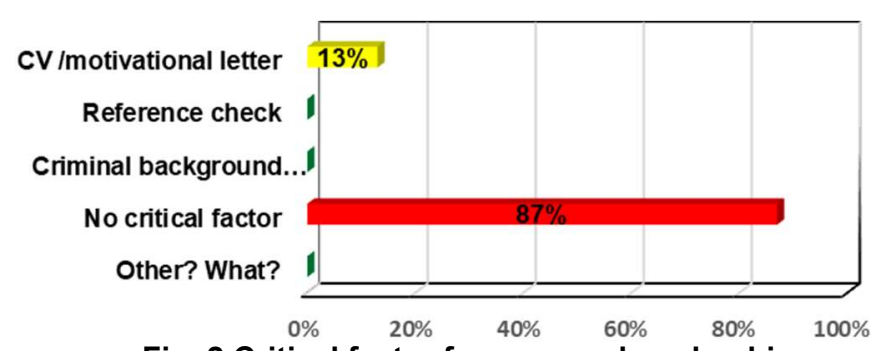

Fig. 2 Critical factor for seasonal worker hire

Further recruitment proceeded based on acceptance/rejection of the proposed remuneration (87\%), candidate assessment (e.g. fitness for the job, efficiency, cognitive ability) $-27 \%$, and other criteria (medical certification for food handlers or age) $-57 \%$ (Fig. 3).

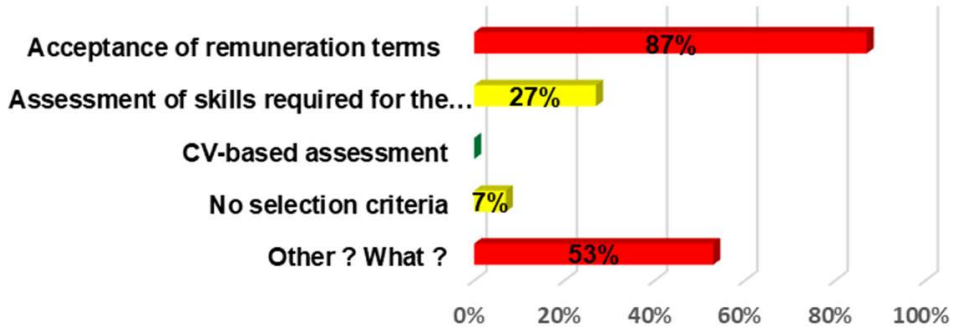

Fig. 3 Selection criteria for seasonal worker hire

Having assessed the restrictions on access of seasonal workers to specific production areas, it was concluded that major restrictions had been introduced only by a small number of the respondents (only 13\%), whereas limited restrictions by $53 \%$ of the respondents. It is somewhat comforting that $27 \%$ of the respondents planned to implement a safety system to prevent unauthorised access. $7 \%$ of the companies did not recognize the need to restrict employee access to production areas (Fig. 4). 


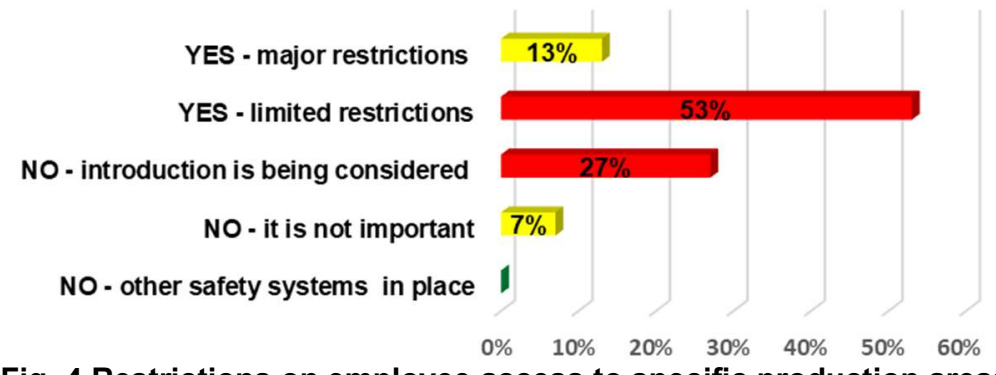

Fig. 4 Restrictions on employee access to specific production areas

Responses to the question: Do seasonal workers are allowed to circulate in all production areas? showed that $60 \%$ basically stayed at their workstations (although they could have access to other areas), 20\% circulated freely, and only $20 \%$ were strictly required to remain in their designated areas of which $13 \%$ were under continuous supervision (Fig. 5).

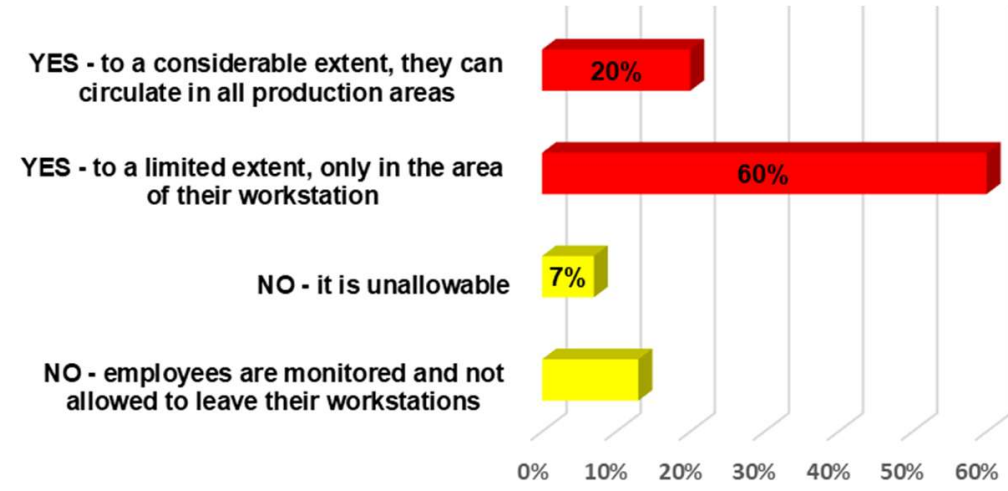

Fig. 5 Production worker circulation in production areas

It is encouraging that there is an interest in CCTV production monitoring systems, some type of which was found to be operated in $60 \%$ of the companies. Nevertheless, only $13 \%$ of the respondents reported the existence of a specialized department responsible for ongoing oversight of production processes (Fig. 6).

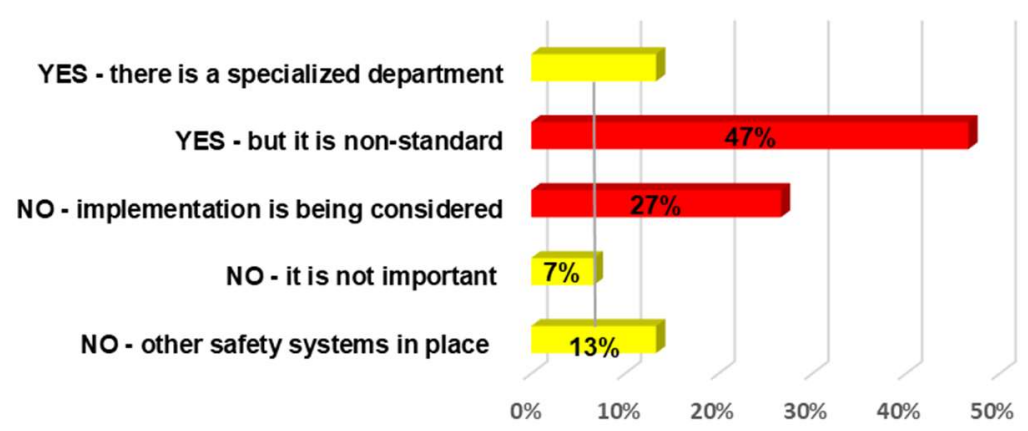

Fig. 6 Availability of CCTV systems and process control

Interesting, vexing, and thought-provoking are the answers submitted to the question: Is there a food quality or a food safety function in the organization? The answers were as follows (Fig. 7):

- YES - very well-established, everything is subject to control - 13\% (a question arises: why such a small percentage? it is food we are dealing with); 
- YES - it mostly relies on checking the appearance (visual control), basic quality check - 60\% (a question arises: whatever happened to laboratories?);

- YES - does not satisfy most of the requirements - 27\% (comment: it deserves a "red card").

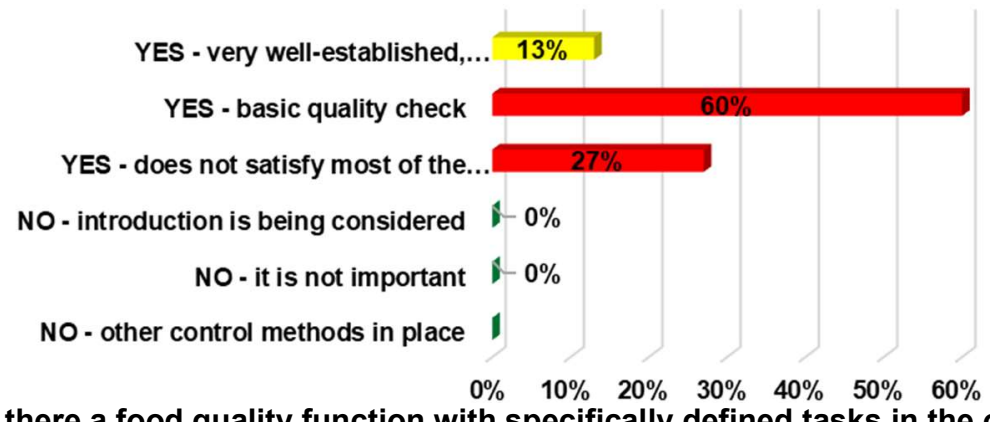

Fig. 7 Is there a food quality function with specifically defined tasks in the organization

The most disturbing problem was revealed by the responses to the question: Is there a risk of food contamination, otherwise known as 'food terrorism', by production workers, including seasonal workers [E]? It turns out that $60 \%$ of respondents answered YES and DEFINITELY YES, which is more than one half (only $33 \%$ provided a NO answer). Debatable is the position taken by the managers who claimed that 'food terrorism' did not exist in real-life production environment, that it was a phoney concept. $7 \%$ of the respondents expressed such an opinion (Fig. 8).

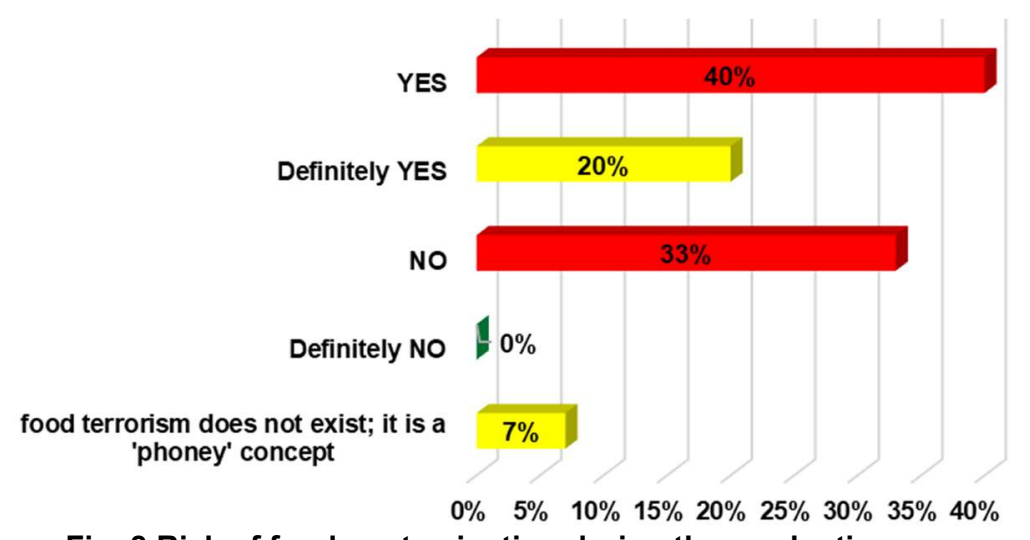

Fig. 8 Risk of food contamination during the production process

\section{CONCLUSIONS}

A cogent dictum that follows from interviews conducted with experts responsible for food manufacturing is this: today's standards for food products for immediate consumption require them to be tasty, nutritional, of highest quality (safe) and freshness. The experts claim that satisfying these requirements is exceptionally challenging, and they cite the following reasons for that (Szymonik, 2015): continual changes in supply, distribution caused by new techniques, technologies, intensive farming (large profits, use of efficient machinery, use of chemicals, fertilizers, insecticides, etc.)

- operation of - an upward trend - super- and hypermarkets, institutional food service companies, and street food vendors 
- changes in the natural environment - it is exposed to contamination/pollution (intentional or unintentional) mainly caused by factors related to the global civilization;

- lengthening supply chains due to procurement of low-cost raw materials from global suppliers and the pursuit of remote markets;

- competitors' business practice, sometimes unethical.

All this is conducive to an increasing likelihood of proliferation of food of poor quality, sometimes contaminated, and many a time posing a threat to human health or human life, and also negatively impacting on the natural environment. It follows from the questionnaire survey that experts are of the opinion that even the best procedures, instructions, advanced techniques and technologies are of no use, if the human being fails. Most experts, during overt, controlled observation, raised the issue related to the risk of contamination by production workers (seasonal) who are largely subject to very limited screening. Overwhelmingly, a majority of them are no longer Polish workers, and their selection during the hiring process basically relies on financial criteria.

Globalization of the food supply chain gives rise to some challenges to management, especially because this type of chain has become increasingly dynamic and industrialized (Roth, 2008). Some of these challenges are food traceability (Alfaro \& Rábade, 2009, Epelbaum \& Martinez, 2014) and tracking (Fritz \& Schiefer, 2009), supply chain dispersion (Rong \& Grunow, 2010) and food distribution (Akkerman, 2010), quality assurance (Ting, 2014), risk assessment (Dani \& Deep, 2010, Wang, 2012), and related trust and commitment among firms (Ding, 2014). Food security refers to the delivery of food 'that is uncompromised by intentional contamination, damage, or diversion within the supply chain' (Marucheck, 2011). Security problems can arise from other people or organizations that intentionally perform actions to alter the food characteristics or disrupt the supply chain to prevent its functionality. Food safety refers to the development of actions to reduce the likelihood of food contamination and prevent the resulting harmful consequences of unsafe food, such as illness and death (Akkerman, 2010, Marucheck, 2011). A supply chain perspective can highlight the safety problems that arise from transfers along the chain, such as improper storage, handling and distribution of the food (Marucheck, 2011).

\section{REFERENCES}

Akkerman, R., P. Farahani and M. Grunow. (2010). Quality, safety and sustainability in food distribution: a review of quantitative operations management approaches and challenges. OR Spectrum 32, p. 863-904.

Alfaro, J.A., and L.A. Rábade. (2009). Traceability as a strategic tool to improve inventory management: a case study in the food industry. International Journal of Production Economics 118, p. 104-10.

Chebolu-Subramanian, V. and G.M. Gaukler. (2015). Product contamination in a multistage food supply chain. European Journal of Operational Research 244, p.164175.

Dani, S. and A. Deep. (2010). Fragile food supply chains: reacting to risks. International Journal of Logistics Research and Applications 13, p. 395-410. 
Ding, M.J., F. Jie, K.A. Parton and M.J. Matanda. (2014). Relationships between quality of information sharing and supply chain food quality in the Australian beef processing industry. International Journal of Logistics Management 25, p. 85-108.

European Food Safety Authority, (2008). Statement of EFSA on the risks for public health due to the presence of dioxins in pork from Ireland.' EFSA Journal 911, p.115.

Epelbaum, F.M.B. and M.G. Martinez. (2014). The technological evolution of food traceability systems and their impact on firm sustainable performance: a RBV approach. International Journal of Production Economics 150, p. 215-224.

European Commission, (2011). The White Paper Roadmap to a Single European Transport Area - Towards a Competitive and Resource Efficient Transport System, final version, Brussels, p. 41.

Fritz, M. and G. Schiefer. (2009). Tracking, tracing, and business process interests in food commodities: a multi-level decision complexity. International Journal of Production Economics 11, p. 317-329.

Halas, E. (2012). Kody kreskowe i inne globalne standardy w biznesie, scientific editor, ILiM, Poznań, p. 337.

Layton, L. and N. Miroff. (2009). The rise and fall of a peanut empire. The Washington Post, February 15, 2009.

Marucheck, A.S., N. Greis, C. Mena and L. Cai. (2011). Product safety and security in the global supply chain: issues, challenges and research opportunities - editorial essay. Journal of Operations Management 29, p. 707-720.

Portalspozywczy.pl, (2018). Musimy współpracować na rzecz bezpieczeństwa żywności. [online] Available at www.portalspozywczy.pl, [Accessed 27 Oct. 2018].

Polsatnews.pl, (2017). Skażenie milionów jaj środkiem owadobójczym. [online] Available at www.polsatnews.pl, [Accessed 15 Oct. 2017].

Reiner, G. and M. Trcka. (2004). Customized supply chain design: problems and alternatives for a production company in the food industry. a simulation based analysis. International Journal of Production Economics 89, p. 217-229.

Resende-Filho, M.A and T.M. Hurley. (2012). Information asymmetry and traceability incentives for food safety. International Journal of Production Economics 139, p. 596-603.

Rong, A. and M. Grunow. (2010). A methodology for controlling dispersion in food production and distribution. OR Spectrum 32, p. 957-978.

Roth, A.V., A.A. Tsay, M.E. Pullman and J.V. Gray. (2008). Unraveling the food supply chain: strategic insights from china and the 2007 recalls. Journal of Supply Chain Management 44, p. 22-39.

Sloane, A. and S. O'Reilly. (2013). The emergence of supply network ecosystems: a social network analysis perspective. Production Planning and Control 24, p. 621639.

Spencer, R. (2009). Two sentenced to death over china melanine milk scandal. The Telegraph, January 22, 2009. Available at: http://tinyurl.com/b722s6.

Szymonik, A. (2015). Bezpieczeństwo żywnościowe, Logistyka 2015/5.

Szymonik, A. (2016). Inżynieria bezpieczeństwa systemów logistycznych, Difin, Warszawa.

Tang, C.S. and V. Babich. (2014). Using social and economic incentives to discourage Chinese suppliers from product adulteration. Business Horizons 57, p. 497-508.

Ting, S.L, Y.K. Tse, G.T.S. Ho, S.H. Chung and G. Pang. (2014). Mining logistics data to assure the quality in a sustainable food supply chain: a case in the red wine industry. International Journal of Production Economics 152, p. 200-209.

Wang, L., H.-B. Shi, S. Yu, H. Li, L. Liu, Z. Bi and L. Fu. (2012). An application of enterprise systems in quality management of products. Information Technology and Management 13, p. 389-402.

Wiadomości.onet.pl, (2017). Niemcy: szantażysta grozi zatruciem żywności w supermarketach. [online] Available at http://wiadomosci.onet.pl, [Accessed 28 Sept. 2017]. 
Wolnemedia.net, (2017). Szwecja wycofała 19 ton polskich jabłek. [online] Available at www.wolnemedia.net [Accessed 15 Oct. 2017].

Van der Gaag, M.A., F. Vos, H.W. Saatkamp, M. Van Boven, P. Van Beek and R.B.M. Huirne. (2004). A statetransition simulation model for the spread of Salmonella in the pork supply chain. European Journal of Operational Research 156, p. 782-798.

\begin{abstract}
.
Food production system, due to the mass scale of its manufacturing, distribution, and consumption, is subject to rigorous protection and control. The analysis of food safety presented in the foregoing publication shows that legal and organizational regulations are not alone sufficient to ensure that the quality of products does not pose a health and environmental threat. The results of the study conducted with the participation of 15 subjects make it evident that the issue of food safety is complex and requires continual monitoring because of ever changing conditions. It is increasingly seen that food safety is a key factor in supply chains, becoming the overriding element of production systems. Production companies spend more and more money on control and modernization of the entire production-related system so that food safety is $100 \%$ guaranteed. In the last few years, it can be seen that audits in manufacturing companies that deal with the production and sale of food are largely focused on food safety, process monitoring systems and employee access controls to individual production zones. Not without significance is the fact that additional departments are created in manufacturing companies, whose main task is to control production processes in terms of food safety, both from the side of the safe use of raw materials, packaging and the interference of unauthorized persons. It is absolutely necessary to emphasize that the paper also shows some examples that can already be treated as the first symptoms of food terrorism, which is becoming a deadly tool for current and future food terrorists. The publication emphasizes that food safety in the market reality of that time may be of paramount importance in the supply chains, given the importance and consequences of possible mass contamination of food.
\end{abstract}

Keywords: production, food, supply chain, safety, logistics, legal regulations, organizational requirements, terrorism 